\title{
FINSK KRÖNIKA 1996-2000
}

\section{AV PROFESSOR DAN FRÄNDE, PROFESSOR MARTTI MAJANEN OCH PROFESSOR ARI-MATTI NUUTILA}

\section{Om finsk kriminalpolitik}

Den finska kriminalpolitiken präglades under åren 1996-2000 av en klar skärpning i attityderna. Kriminalpolitiken fick ett mera fragmentariskt innehåll och politikerna riktade sitt intresse mot enskilda frågeställningar i stället för att satsa på reformer av mera bestående natur. Man överlät inte som tidigare kriminalpolitiken åt experterna, utan den kom allt tydligare att bli föremål för den dagspolitiska diskussionen.

Den ändrade inställningen symboliserades av dåvarande justitieminister Kari Häkämies ofta framlagda påstående om att "den kriminalpolitiska linje som valdes på 1970-talet helt enkelt har nått vägens slut". Högsta domstolen kritiserades ovanligt hårt 1997 och politikernas förtroende för domstolsväsendet hade även i övrigt sjunkit. Följande år krävdes hårdare tag mot främst narkotika-, sexual- och våldsbrott. När Finland under slutet av 1999 fungerade som ordförandeland för EU riktades uppmärksamhet i första hand mot en effektivare bekämpning av den internationella brottsligheten på EU-området. Kännetecknande för hela perioden 1996-2000 var att polisens befogenheter stegvis utvidgades.

Fastän motsvarande utveckling har kunnat iakttas i det övriga Norden har den även inhemska orsaker. Den nya riksåklagaren inledde sin verksamhet 1.12.1997 och åklagarväsendets ställning befästes i den nya finska grundlagen som trädde i kraft 1.3.2000. Riksåklagare Martti Kuusimäkis kriminalpolitiska ställningstaganden har fått stor betydelse. Till K.J. Långs efterträdare som överdirektör för justitieministeriets fångvårdsavdelning valdes 1997 Markku Salminen. Även han deltog särskilt i början av sin tjänsteperiod aktivt i den kriminalpolitiska debatten. Kari Häkämies fungerade flera gången under åren 1996-2000 som justitie- eller inrikesminister. Han var kriminalpolitiskt betydligt aktivare än sina föregångare.

I verkligheten hade brottsligheten under den aktuella perioden inte väsentligt ökat.

Fallen av misshandel och grov misshandel visade en sjunkande tendens. Däremot förekom ett något större antal stölder och olovligt brukande av motorfordon. Endast narkotikasituationen försämrades på samma sätt som i Västeuropa över lag. Som helhet hade dock medborgarna större förtroende för domstolarna än politikerna.

\section{Lagändringar}

2.1. Grundlagen

Finlands riksdag godkände en ny grundlag 1999 (731/1999) och den trädde i kraft 1.3.2000. Redan tidigare, dvs. 1995, hade 2 kap.regeringsformen om grundläggande fri- och rättigheter reformerats. Ur straffrättslig synvinkel är 1995 års reform av grundrättigheterna viktigare, eftersom 1999 års totalrevidering (GL 2 kap.) som helhet övertog grundrättigheterna från 1995. Genom den sistnämnda reformen utökades visserligen katalogen av grundläggande fri- och rättigheter, men i första hand fick grundrättigheterna en större betydelse $\mathrm{i}$ både lagstiftarens och de rättskipande myndigheternas arbete.

Helt nya kriterier gäller i riksdagen för den straff- och processrättsliga lagstiftningen. Lagförslagen sänds betydligt oftare än tidigare till grundlagsutskottet. Strafflagstiftningen begränsas av såväl grundlagen som de internationella förpliktelser som gäller för Finland. Så förutsätter t.ex. den straffrättsliga legalitetsprincipen (GL 8 §) att straffbestämmelserna skrivs allt noggrannare och exaktare. Bruket av blankettstraffbestämmelser är föremål för flera betydelsefulla begränsningar. Vid reformer av lagstiftningen om förundersökning, tvångsmedel och rättegångsförfarande fästs allt större uppmärksamhet på rättsskyddskravet (GL 21 §).

I högsta domstolens avgöranden kommer, vid sidan av vanlig lagtiftning, allt oftare artiklarna i den europeiska konventionen om de mänskliga rättigheterna samt reglerna om grundläggande fri- 
och rättigheter till användning. De flesta prejudikaten gäller frågan om en rättvis rättegång (EMRK 6 artikel, GL 21 §). Under senare år har högsta domstolen även gett flera avgöranden i vilka betonas den straffrättsliga legalitetsprincipen (EMRK 7 artikel, GL 8 §) samt det därtill hörande analogiförbudet. Högsta domstolen har även vägt grundrättigheter mot varandra. Bland annat har yttrandefrihetens förhållande till äran och skyddet av privatlivet varit föremål för behandling. Som ett annat exempel kan nämnas ett avgörande där högsta domstolen vägde den misstänktes rätt att inte medverka i att klara upp den egna skulden och vägtrafiklagens krav på att stanna kvar på olycksplatsen.

I den straffrättsliga litteraturen har man försökt koppla de grundläggande fri- och rättigheterna till de traditionella kriminaliseringsprinciperna och de straffrättsliga tolkningsprinciperna. Reformen av grundrättigheterna förutsätter uttryckligen en bedömning av den teoretiska och praktiska betydelsen hos grundläggande och mänskliga rättigheter både i straffrättens allmänna läror och i straffrättens tolkningsläror.

\subsection{Enskilda brott}

\section{Strafflagsprojektets tredje fas}

Den andra fasen i strafflagens helhetsreform genomfördes 1995 genom lagändringen 578/1995. Strafflagsprojektet, som sedan 1980 förberedde helhetsreformen, genomförde den tredje fasen som delreformer. Vissa brottstyper, en del av påföljdssystemet samt strafflagens allmänna läror återstår att reformera.

Utgående från strafflagsprojektets arbete reformerades bestämmelserna om den finska strafflagens tillämpningsområde (SL 1 kap.) 1996. År 1998 genomfördes reformen av bestämmelserna om brott mot rättskipning, myndigheter och allmän ordning (SL 15-17 kap.) samt bestämmelserna om sexualbrott (SL 20 kap.) De nya bestämmelserna om trafikbrott (SL 23 kap.), böter och ordningsbot (SL 2a kap.) samt värdepappersmarknadsbrott (SL 51 kap.) trädde i kraft 1999. Reformen av reglerna om integritet, frid och ära (SL 24 kap.) samt militära brott (SL 45 kap.) genomfördes 2000. De övriga reformerna förbereddes i huvudsak utanför strafflagsprojektet. För dessa redogörs senare i detta avsnitt.

En del av strafflagsprojektetes reformer var fortfarande under arbete hösten 2000. Betänkandet om strafflagens allmänna läror är på remiss. I riksdagen behandlas som bäst förslagen till nya regler om preskription (SL 8 kap.) och konfiskation (SL 10 kap.). Strafflagsprojektets förslag till regler om verkställighet av fängelsestraff vidarebereds i fängelsestraffkommittén. Huvuddragen av dessa presenteras i avsnitt 3 .

Justitieministeriet avslutade strafflagsprojektet 31.3.1999. Projektets arbete var då till största delen slutfört. De delar som ännu inte har reformerats bereds i justitieministeriets arbetsgrupper på normalt sätt. Till dessa hör bl.a. brotten mot naturresurser samt de brott som äventyrar hälsa och säkerhet (ett nytt SL 44 kap.), det straffrättsliga skyddet av foster, embryon och arvsmassa samt ändringar i reglerna om tjänstebrott (SL 40 kap.). De nya straffbestämmelserna om doping har man för avsikt att placera i SL 44 kap. Man avser även att reformera alkoholbrotten.

\section{Strafflagens kärnområde}

Sexualbrotten i SL 20 kap. genomgick en totalreform 1998 (563/1998). Målet med reformen var att bättre än tidigare skydda den sexuella självbestämmanderätten. Det andra centrala målet var att förbättra barnens straffrättsliga skydd. De bestämmelser som inte direkt gällde den sexuella självbestämmanderätten överfördes till SL 17 kap. Efter reformen står sexualbrotten till största delar under allmänt åtal.

De nya bestämmelserna om sexualbrott är inte längre könsbundna. Till exempel våldtäkt omfattar gärningar som begås både mot en person av samma kön och mot en person av motsatt kön. De särskilda bestämmelserna om en viss skyddsålder vid homosexualitet upphävdes. Efter en livlig diskussion indelades våldtäkten i tre brottstyper (våldtäkt, grov våldtäkt samt tvingande till samlag). Straffskalorna för sexualbrott riktade mot barn höjdes. Prostitutionen kriminaliserades däremot inte, fastän även detta föreslogs. Endast köp av sexualtjänster av personer under 18 år kriminaliserades.

Strafflagens bestämmelser om brott mot rättskipning, myndigheter och allmän ordning reformera- 
des 1998 (563/1998). Avsikten med SL 15 kap. "Om brott mot rättskipning" är att garantera centrala förutsättningar för ett ordnat samhällsliv. Kapitlets inledande paragrafer reglerar olika former av osann utsaga i rättsskipningen. Med osann utsaga avses lämnande av osanna uppgifter eller förtigande av riktiga uppgifter utan lagligt skäl. Bestämmelserna har systematiserats utgående från om utsagan ges inför domstol eller vid något annat myndighetsförfarande. Vittnen, sakkunniga eller parter som hörs under sanningsförsäkran samt vissa personer som hörs under ed eller försäkran kan göra sig skyldiga till osann utsaga inför domstol. Osann utsaga vid myndighetsförfarande aktualiseras främst i samband med förundersökning. SL 15 kap. innehåller även bestämmelser om bl.a. falsk angivelse, övergrepp i rättssak och underlåtenhet att anmäla grovt brott.

SL 16 kap. om brott mot myndigheter kan indelas i fem större grupper. Den första gruppen utgörs av brott som omfattar olika typer av motstånd mot tjänstemän och deras tjänsteåtgärder. Grundbestämmelsen är våldsamt motstånd mot tjänsteman som kan förverkligas genom a) att tvinga en tjänsteman att göra eller underlåta en viss tjänsteåtgärd, $b$ ) att använda våld eller hota med våld med anledning av en tjänsteåtgärd samt $\mathrm{c}$ ) att hämnas med anledning av en tjänsteåtgärd. I samtliga situationer förutsätts att gärningen hänför sig till en tjänsteåtgärd som innebär utövande av offentlig makt. Brottets lindriga form kallas motstånd mot tjänsteman. Den andra brottsgruppen bildas av de bestämmelser som avser att garantera riktigheten av de uppgifter som inlämnas till myndigheter. Här kan nämnas lämnande av oriktiga personuppgifter och bötesfusk. Med hjälp av den sistnämnda kriminaliseringen försöker man förmå den bötfällde att ge riktiga uppgifter om sina inkomster och sin förmögenhet. Bestämmelsens praktiska relevans är ringa, eftersom uppgifterna skaffas direkt av skattemyndigheterna. Den tredje gruppen består av olika typer av olagliga ingrepp i myndigheternas verksamhet, av angrepp mot föremål som är myndighetskontrollerade samt av överträdelser av myndigheters förbud och begränsningar. Hit hör bl.a. brott mot besöksförbud och brott mot näringsförbud.

L om besöksförbud (898/1998) trädde i kraft 1999. Enligt lagen kan tingsrätten meddela besöksförbud för högst ett år, om det finns grundad anledning att anta att den person mot vilken förbudet avses gälla kommer att begå ett brott riktat mot liv, hälsa, frihet eller frid eller allvarligt trakassera den som känner sig hotad. Polisen övervakar efterlevnaden av besöksförbudet och uppsåtliga brott mot förbudet straffas med böter eller fängelse i högst ett år.

Sedan 1986 har L om näringsförbud (1059/1985) varit i kraft i Finland. Bestämmelserna reviderades grundligt 1997. Domstolen kan meddela näringsförbud för minst tre och högst sju år. Näringsförbuden registreras i ett offentligt register som förs av rättsregistercentralen, och tillsynen över att näringsförbuden efterlevs utövas av polisen. Den fjärde brottsgruppen i SL 16 kap. utgörs av mutbrott som riktas mot myndigheter och den femte av brott som riktas mot förvarandet av personer som lagligt har berövats friheten (olaga befriande av fånge, făngrymning och fånges vapeninnehav).

SL 17 kap. om brott mot allmän ordning innehåller mycket heterogena brott. De flesta utmärks av att de inte direkt kränker eller äventyrar andra människors rättigheter eller fördelar utan närmast åstadkommer anstöt eller förargelse. Till denna grupp hör bl.a. offentlig uppmaning till brott, upplopp, brott mot trosfrid, ofog och offentlig kränkning av sedligheten. I detta sammanhang kan även nämnas att under 1999 stiftades en ny lag om sammankomster (530/1999) och om ordningsvakter (533/1999)

SL 45 kap. om militärbrott reformerades 2000 (559/2000). Bestämmelserna skrevs om under beaktande av de principer som har följts i samband med strafflagens totalreform samt de erfarenheter som tillämpningen har gett hittills. Den största materiella förändringen gällde upphävandet av kriminaliseringen av soldaternas politiska verksamhet, eftersom den begränsade beväringarnas yttrandefrihet. Fortfarande förbjuds stamanställda att höra till ett parti eller till en förening som bedriver politisk verksamhet. De i praxis viktigaste bestämmelserna om olovlig frånvaro och rymning, om tjänsteförseelse och missbruk av förmansställning ändrades inte alls.

Straffbestämmelserna om integritet, frid och ära reformerades och samlades i SL 24 kap. Reformen trädde i kraft 2000 (531/2000) och innebar en modernisering av de bestämmelser som till största delen härstammade från 1889. Bestämmelsen om hemfrid förblev i stort intakt, men området för hemfridens utsträckning definieras nu i lagen. 
Bestämmelsen om brott mot offentlig frid utsträckte betydelsen av begreppet inträngande. Med stadgandet skyddas förutom den traditionella ämbetsverksfriden även affärslokaler, byråer, produktionsanläggningar och motsvarande lokaler och byggnader. I ljuset av tidigare rättspraxis var det oklart om det straffrättsliga skyddet sträckte sig till affärslokaler. I praktiken möjliggör bestämmelsen effektivare åtgärder mot djurskyddsaktivister.

Tillämpningsområdet för hemlig observation utvidgades något. Bestämmelsen gäller förutom hemfridssfären även offentliga toaletter, omklädningsutrymmen samt andra motsvarande platser. Ändringen har sin grund i en strävan att sätta gränser för bruket av övervakningskameror. Innehållsmässigt ändrades inte bestämmelsen om hemlig observation.

Det gjordes inga större ändringar i bestämmelserna om hemfridsbrott och spridande av information som kränker privatlivet. Rättspraxis vållar däremot problem ibland, eftersom man inte alltid har beaktat den europeiska människorättsdomstolens avgöranden.

Straffbestämmelserna om trafikbrott reformerades i sin helhet 1999 (545/1999). Alla kriminaliseringar med fängelsehot i fråga om väg-, vatten-, spår-, och lufttrafik koncentrerades till SL 23 kap. Böteshoten för gärningsformer av förseelsetyp ingår dock fortfarande i speciallagarna för respektive trafikform.

Grundrekvisitet för strafflagens trafikbrott är äventyrande av trafiksäkerheten. Med detta avses sådana uppsåtliga eller oaktsamma överträdelser av trafikreglerna som är ägnade att förorsaka fara för någon annans säkerhet. Med brott mot trafikreglerna jämställs underlåtenhet att iaktta den omsorg eller försiktighet som krävs i trafiken. Förutom detta grundrekvisit ingår i SL 23 kap. en bestämmelse om grovt äventyrande av trafiksäkerheten. De lindrigaste överträdelserna omfattas inte av bestämmelsen om äventyrande av trafiksäkerheten. Däremot kan de bestraffas med stöd av VägtrafikL $103 \S$ (trafikförseelse).

Bestämmelserna om rattfylleri ändrades just inte alls $(0,5$ promille som gräns för rattfylleri och 1,2 promille för grovt rattfylleri), men SL 23 kap. innehåller nu alla former av trafikfylleri. Även förande av fortskaffningsmedel utan behörighet och smitning i vägtrafik ingår i SL 23 kap.

\section{Europarätten och strafflagen}

Den viktigaste strafflagsändring som under perioden har initierats av EU genomfördes 1998 och gällde bestämmelserna om skatte- och subventionsbidrag (814/1998). Konventionen om skyddet av Europeiska gemenskapens ekonomiska intressen (den s.k. PIF-konventionen) från 1995 förpliktar medlemsländerna i Europeiska unionen att kriminalisera bedrägeri riktat mot den Europeiska gemenskapens ekonomiska intressen. För den finska straffrättens del betydde detta i praktiken att legaldefinitionen i SL 29:9 av begreppet skatt i skattebedrägeribestämmelsen måste utvidgas till att gälla även tullar och förskott på skatt. På motsvarande sätt kan objektet för subventionsbedrägeri efter reformen härstamma från Europeiska gemenskapens budget. Samtidigt preciserades gärningsrekvisiten för subventionsbedrägeri.

Till PIF-konventionen fogades 27.9.1996 ett s.k. korruptionsprotokoll. Kort därefter, dvs. 26.5.1997, fattade man beslut om den s.k. korruptionskonventionen, något som i sin tur skedde på basis av avtalet om Europeiska unionens s.k. tredje pelare. Också inom ramen för OECD ingicks 17.12.1997 en konvention om hindrande av muta inom internationella affärsrelationer. Finland uppfyllde dessa konventionsförpliktelser så att rekvisitet för givande av muta (SL 16:13) utvidgades till att gälla även främmande staters och EU:s tjänstemän. Kriminaliseringarna av tagande av muta utsträcktes till att gälla alla medlemsstaters tjänstemän samt EU:s tjänstemän.

De medlemsländer som har anslutit sig till PIF-konventionen och korruptionskonventionen förbinder sig att godkänna Europadomstolens kompetens att avgöra tvister mellan medlemsstaterna om tillämpningen och tolkningen av konventionen samt tvister mellan medlemsländerna och kommissionen i fråga om tillämpningen av vissa konventionsbestämmelser. Skyldigheten gäller både bedrägeri- och korruptionsbrott.

Bestämmelserna om penningtvätt genomgick en helhetsreform 1998 i enlighet med det s.k. penningtvättdirektivet. Den viktigaste ändringen gällde utvidgningen av kretsen av anmälningsskyldiga. Bestämmelserna vars mål är att förhindra penningtvätt omfattar förutom penninginrättningar 
bl.a. utländska penninginrättningars filialer, samfund som erbjuder placeringstjänster utöver sin sedvanliga verksamhet, samfund som ordnar penningspel samt fastighetsförmedlare. Lagstiftningen om låneinrättningar ändrades på motsvarande sätt.

Även kontrollen av penningtvätt gjordes klarare. I lagen om förhindrande och utredning av penningtvätt intogs regler om grundandet av en utredningscentral för penningtvätt $i$ samband med centralkriminalpolisen. Centralen tar emot de i lagen angivna anmälningarna och den har rätt att få tillräckliga uppgifter för utredningen av anmälningarna.

Ändringen av strafflagen 298/2000 hör samman med skyddet av euron. Här utvidgades strafflagens definition av penningar till att gälla även sådana sedlar och metallmynt som ännu inte har släppts ut på marknaden (SL 37:12,3). Man ville med ändringen särskilt försäkra sig om att eurosedlarna och metallmynten som 1.1.2002 tas i bruk åtnjuter straffrättsligt skydd mot förfalskning redan innan de kan användas som lagliga betalningsmedel. Bakom lagändringen står ett beslut av Europeiska gemenskapernas råd.

\section{Övriga reformer som hör samman med den ekonomiska brottsligheten}

Efter en livlig diskussion kompletterades 1997 gärningsbeskrivningen i skattebedrägeribestämmelsen (SL 29:1) så att den omfattade underlåtelser att uppfylla sådana plikter som rör fastställandet av skatt och som har betydelse för gärningsmannan eller någon annan för bestämmandet av skatt. Detta passiva skattebedrägeri kan leda till straff även när myndigheten inte har uppmanat den skattskyldige att göra anmälan. Behovet av kriminaliseringar hänför sig i första hand till medvärdesbeskattningen som i rätt hög grad grundas på den skattskyldiges egna anmälningar. En stor del av den grå ekonomin har konstaterats fungera helt utanför myndighetskontrollen. Efter ikraftträdandet har det passiva skattebedrägeriet i praxis blivit den mest tillämpade formen av skattebedrägeri.

Straffbestämmelsen om värdepappersmarknadsbrott genomgick en totalreform 1999. De straffbestämmelser som innehåller fängelsehot har koncentrerats till SL 51 kap. (475/1999). Delvis påverkades reformen av EU-regleringen av kapitalets fria rörlighet. Bestämmelsen om missbruk av insiderinformation utsträcktes till att gälla vem som helst som uppsåtligen missbrukar insiderinformation. Förutom uppsåt räcker grov oaktsamhet till för straffansvar. Strafflatituden för den grova formen av missbruk av insiderinformation höjdes. Andra brottstyper i kapitlet är kursmanipulation och informationsbrott som gäller värdepappersmarknaden. Värdepappersmarknadsbrotten hör till tillämpningsområdet för juridiska personers straffansvar (SL 9 kap.). De nya reglerna blev nödvändiga, eftersom finansinspektionen under de senaste åren har avslöjat flera fall av värdepappersmarknadsbrott.

Av de enskilda reformerna kan nämnas SL 34:9a som kriminaliserar orsakande av fara för informationsbehandling (951/1999). I sak är det fråga om kriminalisering av tillverkning och spridning av datavirus. Om viruset förorsakar stor skada tillämpas bestämmelsen om grov skadegörelse. Regleringen grundas delvis på för Finland förpliktande internationella överenskommelser. Ytterligare kan nämnas begränsningen av tillämpningsområdet för arbetarskyddsbrott (SL 47:1, 205/1999). Eftersom brotten inte känner någon lindrig form, måste alla fall behandlas inom den normala straffprocessen. Den obligatoriska domstolsbehandlingen av lindriga och enkla arbetsskyddsbrott var processekonomiskt oändamålsenlig och oskälig för parterna. Detta ledde i sin tur till ett stort antal åtalseftergifter. Efter reformen behandlas ringa arbetarskyddsbrott som överträdelser av ArbetsskyddsL och kan avgöras i strafforderförfarande.

\section{Internationell straffrätt}

SL 1 kap. om den finska straffrättens tillämpningsområde reformerades redan 1996 (626/1996). Tilllämpningsområdet inskränktes något i syfte att göra den finska lagstiftningen mera överensstämmande med folkrättens krav. Den viktigaste reformen gällde kravet på dubbel straffbarhet. På brott som en finländare begår utomlands tillämpas finsk lag, om gärningen är straffbar även enligt gärningsortens lagstiftning. Om en finländare utomlands utsätts för ett brott, förutsätts förutom dubbel straffbarhet enligt huvudregeln att gärningen enligt finsk rätt kan ge ett fängelsestraff på över sex månader. Oberoende av gärningsortens lag kan finsk lag enbart tillämpas på sådana internatio- 
nella brott som grundar sig på bestämmelser i internationella konventioner. Listan på internationella brott har blivit mycket lång.

Åtal i Finland för brott begångna utomlands förutsätter fortfarande i regel ett åtalsförordnande av riksåklagaren. En laga kraft vunnen dom hindrar att saken på nytt behandlas i Finland (ne bis in idem), ifall den har avgjorts i den stat där brottet har begåtts eller i en EU-stat. I fråga om EU-staterna grundades ändringen på en EU-konvention (814/1998).

Mellan EU-staterna togs i bruk ett förenklat utlämningsförfarande med anledning av brott och konventionen inarbetades i den finska utlämningslagen 1999 (182/1999). Även utlämningskonventionen mellan EU-länder från 1996 beaktades i samma lagändring. Tyvärr är utlämningsförfarandet mellan EU-länder betydligt mera invecklat än det som gäller mellan de nordiska länderna. I fortsättningen strävar EU efter att ytterligare förenkla utlämningsförfarandet. En av förebilderna är just det nordiska samarbetet inom utlämningsrätten.

Till sist kan en liten men principiellt viktig ändring nämnas. Finlands internationella förpliktelser ledde 1997 till att bruket av kemikaliska vapen förbjöds i strafflagen (SL 11:7a, 351/1997). Den konvention som lagändringen grundade sig på hade utarbetats inom FN:s regi och den är den första som förbjuder utveckling, produktion, lagerhållning och bruk av ett visst vapenslag.

\subsection{Påföljderna}

Från början av 1997 hör samfundstjänsten till de ordinära huvudstraffen i Finland. Den tidigare lagen om försöksverksamhet med samhällstjänst, som ursprungligen gavs 1991, gjordes permanent genom L om samhällstjänst (1055/1996). I februari 1997 inleddes försöksverksamhet med ungdomsstraff (1058/1996) på sju orter i landet. Lagen var ursprungligen avsedd att gälla tre år framåt. Ungdomsstraffet, som förutsätter att gärningsmannen är mellan 15-17 år när brottet begicks, består av övervakning mellan fyra månader och ett år samt av ungdomstjänst mellan 10 och 60 timmar.

Under de två första åren har bruket av ungdomsstraff varit mindre än väntat (1997: 46, 1998: 45). Detta berodde delvis på att propositionen utgick från att ungdomsstraffet i första hand skulle användas när den unga personen redan hade ådömts åtminstone ett villkorligt straff. För att möjliggöra bruket av ungdomsstraff i syfte att bryta en brottsspiral redan innan något villkorligt straff har hunnit dömas ut, intogs i försökslagen en utsaga om att ungdomsstraff även kan användas för att förhindra återfall i brott och för att främja gärningsmannens möjligheter att anpassa sig i samhället. År 1999 visade det sig nödvändigt att förlänga försökslagens giltighetsstid till utgången av 2001.

Förordningen om försöksverksamhet med ungdomsstraff ändrades 2000 i syfte att göra verkställigheten av ungdomsstraff snabbare. Åtgärden hör till en större paket med vars hjälp man strävar efter att påskynda behandlingen av unga personers brott $\mathrm{i}$ alla instanser allt från förundersökning till verkställighet. Justitieministeriet har 1999 tillsatt en arbetsgrupp som har till uppgift att planera, leda och övervaka försöken att försnabba behandlingen av unga personers brott.

Reglerna om böter, förvandlingsstraff och ordningsbot samlades $1999 \mathrm{i}$ en något reformerad form i SL 2a kap. (550/1999). Man övergav samtidigt bestämmandet av dagsbotens belopppå basis av bruttoinkomsterna. Enligt gällande rätt räknas dagsbotens belopp utgående från de skattepliktiga förvärvs- och kapitalinkomsterna, från vilka har avdragits skatter och vissa avgifter. Från inkomsterna görs ytterligare ett baskonsumtionsavdrag som i dag är $1.500 \mathrm{mk}$. Dagsbotens belopp är 1/60 av månadsinkomsten beräknad på beskrivet sätt. Dagsbotens penningbelopp bestäms på basis av skatteuppgifter som erhålls direkt av skattemyndigheterna. Dagsbotens belopp ökas av en förmögenhet på över $500.000 \mathrm{mk}$ samt minskas ifall den bötfällde är underhållsskyldig. Det minsta beloppet för en dagsbot höjdes från $20 \mathrm{mk}$ till $40 \mathrm{mk}$. Latituden för dagsböter vid ett brott är fortfarande 1-120, om inte lagen innehåller undantag från huvudregeln. Utdöms samtidigt böter för flera brott utgör 240 dagsböter maximum.

Obetalda böter enligt dagsbotssystemet och ett obetalt vite utdömt $i$ visst penningbelopp kan fortfarande förvandlas till fängelse. Huvudregeln är alltjämt att två obetalda dagsböter motsvarar en dags fängelse och varje hundra mk av vitet motsvarar en dags fängelse. Det lägsta förvandlingsstraffet är 4 dagars och det högsta 90 dagars fängelse. Under vissa förutsättningar kan förvandlingsstraffet underlåtas, till exempel om det brott som gav böterna begicks innan gärningsmannen hade fyllt 
18 år eller om förvandlingsstraffet är att anse som oskäligt eller oändamålsenligt med hänsyn till den bötfälldes personliga förhållanden.

I samband med reformen justerades tillämpningsområdet och beloppet för ordningsboten som är ett till markbeloppet fixerat straff. Gränsen för ordningsbot vid fortkörning i vägtrafik höjdes från $15 \mathrm{~km} / \mathrm{t}$ till $20 \mathrm{~km} / \mathrm{t}$, varvid beloppen även graderades. Ordningsboten vid fortköring kan beroende av det konkreta fallet vara 400, 500, 600 eller $700 \mathrm{mk}$. Ordningsbot kan även bestämmas för en rad lindriga trafikförseelser med början vid $50 \mathrm{mk}$ för fotgängare. Det är trafikförseelserna som nästan helt dominerar ordningsboten. Det enda undantaget utgörs av överträdelser av nedskräpningsförbud som ger en ordningsbot om $300 \mathrm{mk}$. Ordningsbot kan inte förvandlas till fängelse.

Vissa bestämmelser i lagen om verkställighet av straff ändrades 1999 (364/1999). Avsikten var att effektivera narkotikakontrollen i fängelserna. Möjligheterna att genomföra kroppsvisitation och kroppsbesiktning, urin- och utandningsprov utökades. I lagen intogs nya bestämmelser om särskilda säkerhetsavdelningar. En fănge kan placeras i en sådan avdelning bl.a. om det finns grundad anledning att misstänka honom för spridning av narkotika eller om han allvarligt äventyrar säkerheten vid anstalten. Om det är motiverat med hänsyn till fångens egen säkerhet kan en placering i säkerhetsavdelning göras.

\subsection{Straffprocessrätten}

Under perioden har den finska straffprocessen genomgått en radikal förändring. Från och med 1.10.1997 regleras den finska brottmålsrättegången av L om rättegång i brottmål (689/1997). Dock är BRL inte heltäckande utan man måste även beakta de med civilprocessen gemensamma reglerna i rättegångsbalken. Det finns planer på att försöka återskapa den stora Balken, men det kommer att vara en annan historia. Genom BRL övergick man i Finland till en modern straffprocess med en koncentrerad och muntlig huvudförhandling. Särskilt i de större städerna har dock den gamla ordningens uppskov ersatts med inställda huvudförhandlingar.

Det säger sig självt att den nya processen kräver en effektiv åklagarkår, något som erhölls genom att åklagarna 1997 reorganiserades i häradsåklagare på gräsrotsnivån. Över dessa står riksåklagarämbetet med riksåklagaren i spetsen. Riksåklagarämbetets hårda kärna består av statsåklagare som ansvarar för de ur samhällets synvinkel mest betydelsefulla målen. Efter detta har riksdagens justitieombudsman och justitiekanslern ställning av specialåklagare i åklagarhierarkin.

Samtidigt som åklagarsidan klart förstärktes beslöt man att i viss mån inskränka målsägandens processuella rättigheter. Det kan samtidigt konstateras att BRL saknar en allmängiltig legaldefintion av vem som skall anses vara målsägande. Här gäller således tidigare rättspraxis fullt ut. Både beträffande brott under allmänt åtal och målsägandebrott måste målsäganden enligt huvudregeln framställa en åtalsbegäran till en behörig åklagare (tekniskt kan begäran framställas under förundersökningen och riktas till polisen), innan målsäganden på egen hand kan inleda en straffprocess mot den påstådda gärningsmannen. Enligt det gamla systemet hade målsäganden en med åklagaren parallell åtalsrätt. Det bör dock påpekas att bl.a. kostnadsansvaret gör målsägandedrivna brottmål mycket ovanliga.

I reformen bevarades begreppet målsägandebrott. I den finska kontexten innebär målsägandebrott vissa utpekade brottstyper med den egenarten att allmänna åklagaren enligt huvudregeln saknar åtalsrätt, om inte målsäganden framställer en åtalsbegäran.

Som ett slags motvikt till målsägandens minskade behörighet är allmänna åklagaren enligt BRL skyldig att driva målsägandens privaträttsliga krav på grund av brottet. Endast ifall kravet är klart ogrundat eller det annars skulle vålla extra arbete för åklagaren, får han vägra.

Man beslöt hålla kvar polisens ansvar för förundersökningens genomförande. Det fanns planer på att låta åklagaren blir undersökningsledare när någon kunde misstänkas för ett brott, men tanken övergavs innan regeringens proposition 82/1995 avläts. Nu finns endast en bestämmelse i förundersökningslagen om att förundersökningsledaren skall underrätta åklagaren när någon kan misstänkas för brottet och saken inte är enkel.

Vad gäller själva brottmålsprocessen kan konstateras att den inleds med att allmänna åklagaren till rättens kansli inlämnar en stämningsansökan. Det är enligt BRL möjligt att hålla en muntlig förbere- 
delse, men så sker förhållandevis sällan. Målet blir anhängigt genom stämningsansökan, men preskriptionen avbryts först i samband med att den åtalade personligen delges stämningsansökan.

I jämförelse med tidigare rätt kan de stora förändringarna sammanfattas enligt följande:

Uppskovsförbud. Det är numera möjligt att uppskjuta huvudförhandlingen inom mycket snäva ramar. I första hand skall huvudförhandlingen inställas om det visar sig att det finns något hinder för en koncentrerad behandling. Ifall ett uppskov ändå blir nödvändigt (t.ex. när något centralt vittne insjuknar), måste hela huvudförhandlingen hållas på nytt om uppskovet har varat över 45 dagar. Detta gäller dock inte uppskov för undersökning av den åtalades sinnestillstånd.

Huvudförhandlingens muntlighet. Tidigare var det vanligt att domstolen som rättegångsmaterial använde sig av ett förundersökningsprotokoll utan att någon direkt hade åberopat utsagorna i protokollet. Enligt den nya straffprocessen utgör endast det som muntligen läggs fram under huvudförhandlingen lagligt rättegångsmaterial. Ifall den åtalades berättelse vid huvudförhandlingen avviker från det han har anfört vid polisförhöret, är det åklagarens sak att påpeka detta samt explicit åberopa den första berättelsen. Många domare bekantar sig inte på förhand med förundersökningsmaterialet.

Vittnesförhör enligt den ackusatoriska modellen. Enligt huvudregeln skall den som har utnämnt ett vittne även ha hand om huvudförhöret. Detta ger domstolen möjlighet att koncentrera sig på det som sägs i förhöret.

En frikänd åtalads rätt till ersättning för rättegångskostnaderna. I samband med tillkomsten av BRL kunde ingen konsensus uppnås om den åtalades rätt till ersättning för rättegångskostnaderna $\mathrm{i}$ det fall att åtalet förkastas eller avvisas utan prövning. Av denna orsak kunde den gamla ordningen fortsätta, vilket betydde att en åtalad som vann målet fick svara för sina kostnader själv. I samband med att systemet med allmän rättshjälp reformerades sommaren 1998 fattades även beslut om att en åtalad som frikänns skall få ersättning av staten för sina rättegångskostnader. Denna principiellt mycket viktiga ändring trädde i kraft 1.1.1999. Om det nuvarande systemet må ytterligare konstateras att domstolen för den åtalade kan utse en offentlig försvarare. Detta kan även ske mot hans vilja. Redan i samband med tillkomsten av BRL förstärktes målsägandens ställning i och med att det blev möjligt att förordna ett målsägandebiträde eller en stödperson för honom.

Möjligheten att döma till straff trots att den åtalade inte personligen deltar vid huvudförhandlingen. Under den gamla ordningen förutsattes för en fällande dom alltid att den åtalade hade hörts med anledning av åtalet. I mindre mål skedde hörandet ofta via ombud. I dag är det möjligt att en frånvarande åtalad döms till högst tre månaders fängelse. Dock krävs att stämningen till huvudförhandlingen innehåller en utsaga om denna möjlighet. Ifall den åtalade skriftligen till domstolen inlämnar sitt godkännande, kan straffet vara högst sex månaders fängelse.

Förbud att ändra talan och åtalsbundenhet. Ur den åtalades synvinkel är införandet av ett klart förbud mot att ändra talan en central förstärkning av rättsskyddet. Förarbetena till BRL tog mycket sparsamt ställning till det närmare innehållet i förbudet och bl.a. genom rättpraxis och doktrin har tolkningen starkt orienterats mot rättsläget i Sverige. Rättskraftens negativa utsträckning avgör frågan om det rör sig om en förbjuden taleändring eller en tillåten åtalsjustering.

Även en bestämmelse om domstolens bundenhet intogs i BRL. Idén är förhållandevis enkel; endast de gärningsmoment som har åberopats av åklagaren făr läggas till grund för en fällande dom. Någon mera utvecklad rättspraxis existerar inte ännu och det är för tidigt att säga hur den närmare tolkningen kommer att gestaltas.

Ytterligare bör nämnas att hovsrättsprocessen genomgick en totalreform 1.5.1998 (165/1998). Då trädde nya regler i kraft för hur rättegången i hovrätten skall gestaltas. Reformens viktigaste syfte var att öka antalet muntliga huvudförhandlingar i hovrätten. Enligt huvudregeln skall huvudförhandling alltid hållas om parterna bestrider underrättens bevisprövning. Nyordningen har redan lett till målanhopningar i landets sex hovrätter och man överväger nu att inskränka rätten till huvudförhandling i överrätten. 
3. De viktigaste lagförslagen

Straffrättens allmänna läror

Strafflagsprojektets sista förslag överläts till justitieministern i maj 2000. Det är fråga om en reform av de bestämmelser som berör straffrättens allmänna läror. Avsikten är att i strafflagen inta bestämmelser om de allmänna förutsättningarna för straffrättsligt ansvar, om ansvarsfrihetsgrunder, om försök och delaktighet, om straffarter och valet av straffarter samt om straffmätning. Reformen berör kap. 3-6 i den gällande strafflagen. Under hösten 2000 är förslaget på remiss. Utgående från remissvaren kommer ett justerat förslag att utarbetas och det utgör grunden för det utlåtande som inbegärs av HD. Avsikten är att överlåta regeringens proposition till riksdagen i december 2001.

En av de grundläggande principerna i förslaget är teorineutralitet. Man har gått in för att ge bestämmelserna en sådan form att de inte binds till någon viss teoretisk syn på brottsbegreppet. Likaså har man försökt använda ett begripligt språk, eftersom lagtexten inte enbart riktar sig till dem som dagligen sysslar med straffrätt utan också till lekmän. Samtidigt har man inte kunnat undvika rekvisitbegreppet i förslaget.

Ett annat centralt mål har varit att förstärka legalitetsprincipens ställning i de allmänna lärorna. I dag innehåller t.ex. lagen ingen definition av underlåtenhetens straffbarhet, inte heller av uppsåt och oaktsamhet. Man föreslår nu att samtliga allmänna förutsättningar för straffrättsligt ansvar förutom samtycket intas i lagtexten. Samtidigt har man fortfarande önskat hålla kvar en viss prövningsrätt för domstolarna. Särskilt bestämmelserna om rättfärdigande och ursäktande grunder föreslås få en utformning som även i fortsättningen ger domstolarna en betydande prövningsrätt.

Materiellt strävas inte med bestämmelserna efter några större förändringar i jämförelse med gällande regler eller den dogmatik som har utvecklats i rättslitteraturen och i rättspraxis. Den livligaste diskussionen har uppsåtsdefinitionen väckt. Likaså har olika uppfattningar framförts om den föreslagna utvidgningen av domstolens påföljdsprövning i situationer där det föreligger någon strafflindringsgrund.

\section{Strafflagens speciella del}

Tidigare i avsnitt 2.2. har nämnts att vissa reformer av strafflagens särskilda del väntar på att bli genomförda. Några regeringspropositioner har ännu inte avlåtits till riksdagen, men avsikten är att dessa ges åren 2000-2002.

Av de ändringar som hösten 2000 behandlas av riksdagen kan nämnas regeringens proposition till komplettering av strafflagen med en bestämmelse som kriminaliserar deltagandet $i$ en brottslig organisations verksamhet (RP 183/1999). Bakom propositionen ligger å ena sidan gemensamma nordiska ansträngningar för bekämpning av motorcykelgängens våldsdåd, å andra sidan EU:s åtgärder mot den organiserade brottsligheten. Målet är att skapa en sådan kriminalisering av deltagandet $\mathrm{i}$ kriminella organisationers verksamhet att den uppfyller de krav som EU ställer. Behovet av en sådan nykriminalisering är en kontroversiell fråga. Reformen betyder de facto en utsträckning av den traditionella förberedelsekriminaliseringen. Likaså ökas möjligheterna kraftigt att nyttja tvångsmedel mot t.ex. djurskyddsaktivisters verksamhet.

\section{Internationell straffrätt}

Som ett av de första europeiska länderna står Finland i beråd att implementera grundstadgan för den internationella brottmålsdomstolen. Regeringens proposition i saken (RP 161/2000) har avlåtits till riksdagen i slutet av 2000. Tekniskt sker godkännandet genom stiftandet av en lag om grundstadgans ikraftträdande samt genom vissa ändringar i strafflagen.

\section{Förundersökning och tvångsmedel}

Riksdagen behandlar hösten 2000 en omfattade regeringsproposition med förslag till ändring av polislagen (RP 34/1999). Enligt förslaget skall polislagen kompletteras med bestämmelser om okonventionella brottsbekämpnings- och förundersökningsmetoder. Det nya som föreslås är täckoperation (infiltration) och skenköp. Propositionen innehåller även bestämmelser om säkerhetsgranskningar vid tillfällen som kräver specialskydd. Även rätten för polisen att fă tillgång till identi- 
JOURNAL OF SCANDINAVIAN STUDIES IN
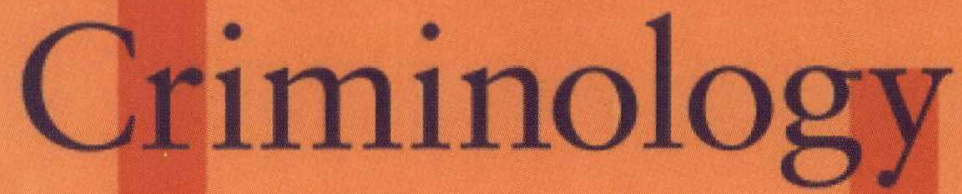

and

Crime

Prevention

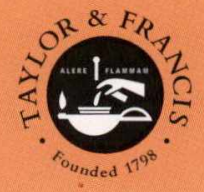




\section{JOURNAL OF SCANDINAVIAN STUDIES IN}

\section{Criminology and Crime Prevention}

The Scandinavian Research Council for Criminology, together with the Nordic national crime prevention councils have launched a scientific biannual journal, the Journal of Scandinavian Studies in Criminology \& Crime Prevention. The predecessors of the journal are the yearbook Scandinavian Studies in Criminology, and the biannual review Studies on Crime \& Crime Prevention.

The new journal is intended to have a different profile from the standard international journals in this field. The publishers have felt that there continues to be a special justification and a demand for a forum where a Nordic perspective is the leading principle for the inclusion of papers.

Reflecting the different backgrounds of the publishers, the new journal endeavors to combine criminological and crime prevention oriented scientific works. Some of the major advances in criminological theory over the past two decades have come about in the realm of developing crime prevention perspectives that have, developed into one of the the central topics of modern scientific criminology.

The journal will present a variety of articles that may at times deviate from the standard format of scientific journals. This is part of an established Scandinavian criminological tradition, reflecting the particular position of the science in societal policy-related debate. In that debate, the heavy "scientific" format is not the only one. This matter of style must not, however, be taken as a signal of non-scientific work. On the contrary: all the texts follow critical scientific standards. In addition, they often express a keen interest in decision-making. 


\section{JOURNAL OF SCANDINAVIAN STUDIES IN}

\section{Criminology and Crime Prevention}

\section{A selection of representative articles}

Social Control and Emancipation - Ambiguities in Child Welfare Kjersti Ericsson

Crime is part of the problem: Contexts of Lethal Violence in Finland and the USA Jukka Savolainen, Steven F Messner and Janne Kivivuori

Criminal Violence and Youth in Sweden: a Long-term Perspective Hanns von Hofer

Crime and Punishment in Norwegian Mid-adolescents: a Normal Population Study Willy Pedersen

Prisoners, Prisons and Punishment in Small Societies

Erlendur Baldursson

The fall of the Finnish Prison Population

Tapio Lappi-Seppälä

Supervision of offenders: Can an old-fashioned service system be of any service in the case of present-day offenders?

Britta Kyvsgaard

\section{Editor}

Kauko Aromaa

National Research Institute of Legal Policy

PO Box 1200

Kansakoulukatu 1A

FIN-00101 Helsinki, Finland

Tel: +358 918257850

Fax: +358918257865

E-mail: kauko.aromaa@om.vn.fi
ISSN: $1404-3858$

Issues per year/volume: 2

Volume in 2000: 1

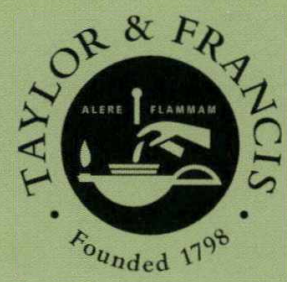




\section{Library Recommendation}

If you feel that your library should subscribe to Journal of Scandinavian Studies in Criminology and Crime Prevention, please pass your positive advice on to your librarian.

To the librarian: (Name)

I recommend the Journal of Scandinavian Studies in Criminology and Crime Prevention for acquisition for our library/department. Please purchase.

Dept.:

Tel.:

\section{ORDER FORM}

Send to: Taylor \& Francis, PO Box 6397, Basingstoke, RG24 8QS, UK

Fax: + 44 (0) 1256330245 , E-mail: orders@tandf.co.uk

U.S. Address: Taylor \& Francis Inc, 47 Runway Road, Suite "G", Levittown,

PA 19057-4700, USA

Tel: +18008218312 or +12152690400 Fax: +12152690363

Email: info@taylorandfrancis.com

Please enter my/our subscription to Journal of Scandinavian Studies in Criminology and Crime Prevention, starting with issue 1, vol. 9, 2000 at the rate checked below.

SUBSCRIPTION RATES 2000:

- Institutions: USD 99

Individuals: USD 49
SUBSCRIPTION RATES 2001:

Institutions: USD 103

口 Individuals: USD 51

Two issues per year. Postage included. Prices are subject to change without notice.

Prepayment required. ISSN: $1404-3858$

- Please send me a free sample copy of Journal of Scandinavian Studies in Criminology and Crime Prevention

\section{PLEASE TICK ONE BOX:}

$\checkmark$ Cheque enclosed

$\square$ Diners
Please send invoice

Mastercard/Eurocard
American Express

๑ VISA

Card no:
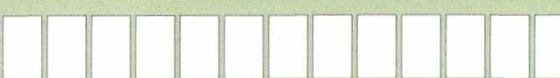

Exp. date:

Make cheque payable to Taylor \& Francis and staple it to your order.

\section{Please use block letters}

Name:

Signature:

Address: 
fikationsuppgifter rörande telemeddelanden samt att utföra teknisk observation föreslås bli utvidgade. Därtill skulle reglerna om handräckning preciseras. Förslaget har gett upphov till en omfattande diskussion för och emot.

Justitieministeriet har förberett ett förslag om ändring av förundersökningslagen och tvångsmedelslagen. Avsikten är att avge en regeringsproposition under våren 2001. Förundersöknings- och tvångsmedelslagstiftningen gås igenom som en helhet och bl.a. behovet av ändringar i reglerna om anhållande, häktning, husrannsakan, skingringsförbud och kvarstad utreds. Regeringen kommer sannolikt att föreslå att teleavlyssning utsträcks till att gälla även allvarlig ekonomisk brottslighet samt att användningsområdet för teknisk avlyssning (s.k.buggning) utvidgas.

\section{Påföljdssystemet}

Riksdagen behandlar hösten 2000 regeringens proposition (RP 27/1999) med förslag till bestämmelser om straffrättslig preskription (SL 8 kap.). De nya bestämmelserna grundas i huvudsak på gällande rätt. Den viktigaste ändringen gäller möjligheten att förlänga preskriptionstiden för åtalsrätten, om gärningsmannen håller sig undan delgivning av stämningen eller om förundersökningen förutsätter särskilt tidskrävande efterforskningsmetoder. Beslutet om att förlänga preskriptionstiden fattas av allmän domstol på begäran av åklagaren. I propositionen föreslås även att den särskilda preskriptionstiden för målsägandebrott avskaffas.

Riksdagen behandlar också regeringens proposition (RP 80/2000) med förslag till regler om förverkandepåföljder. Syftet är här att förenhetliga de disparata konfiskationsreglerna i gällande rätt. De nya och enhetliga bestämmelserna föreslås ingå i SL 10 kap., som bl.a. skulle innehålla regler om konfiskationens allmänna förutsättningar, förverkande av brottsnyttan och brottsredskapet samt förverkande av annan egendom som hör samman med brott. Största delen av de konfiskationsbestämmelser som i dag ingår i SL och i annan lagstiftning förelås bli upphävda.

Propositionen innehåller bestämmelser om utvidgad konfiskation av brottsnyttan i fråga om grova brott som ger ekonomisk nytta. Regeringen föreslår att ett system med omvänd bevisbörda tas i bruk särskilt vid nyttokonfiskationen i samband med narkotikabrott och grova ekonomiska brott. Likaså skall även annan egendom än den som har förvärvats genom det $\mathrm{i}$ åtalet nämnda brottet kunna förverkas till staten. Det skall även bli lättare att förverka egendom som tillhör tredje man. Till denna del är förslaget mycket kontroversiellt.

Regeringens proposition med förslag till nya bestämmelser om villkorligt straff avgavs till riksdagen i slutet av 2000 (RP 177/2000). Enligt förslaget förblir innehållet i det villkorliga straffet i stort intakt. Ett fängelsestraff på högst två år skall fortfarande kunna dömas ut villkorligt, om inte brottets svårhet eller gärningsmannens skuld eller tidigare brottslighet förutsätter ett ovillkorligt straff. Liksom nu skall det villkorliga straffet knytas till hotet att ett nytt fängelsestraff under prövotiden leder till att det villkorliga straffet verkställs.

Som tilläggsstraff till villkorligt fängelse kunde fortfarande utdömas böter. Det föreslås att samhällstjänst också skall kunna användas som tilläggsstraff. Samhällstjänsten avses vara något kortare än när den utdöms som ett självständigt straff $i$ stället för ovillkorligt fängelse.

Den 23.9.1999 tillsatta fängelsestraffkommittén har till uppgift att reformera fängelsestraffets innehåll. Kommittén kommer att lägga fram ett förslag till ny lagstiftning om verkställighet av fängelsestraff. Villkorlig frigivning, därtill hörande övervakning, livstidsfängelse, farliga återfallsförbrytare och ungdomsfängelse är områden som berörs av reformen.

Utgångspunkten är att den villkorliga frigivningen fortsättningsvis utgör en del av straffsystemet. Däremot utvecklas övervakningen samt eftervården. En viktig specialfråga gäller möjligheten att villkorligt frige personer som har dömts till livstidsfängelse. Kommittén har tid att arbeta till 31.3.2001, varefter en regeringsproposition skall avges till riksdagen.

\section{Straffrättslig och straffprocessrättslig forskning}

Man kan på goda grunder hävda att perioden innehåller mycken högtstående straffrättslig och straffprocessrättslig forskning. Den behandlas nedan i tre grupper: doktorsavhandlingar, monografier samt kommentarer och läroböcker. Även verk som innehåller material från andra rättsområden har 
beaktats under förutsättning att det straffrättsliga respektive straffprocessuella har en klar plats i sammanhanget. Det bör observeras att de publikationer som har getts ut av rättspolitiska forskningsinstitutet inte ingår i förteckningen. De engelska sammanfattningarna hittas på internet under adressen http://www.om.fi/optula/.

a. Under den aktuella tiden har flera doktorsavhandlingar framgångsrikt försvarats. De flesta har publicerats på finska, men de innehåller alla en sammanfattning på engelska eller tyska. Ifall boken har recenserats på något annat språk än finska, anges var recensionen har publicerats.

I december 1996 disputerade Ari-Matti Nuutila på avhandlingen "Rikosoikeudellinen huolimattomuus". Arbetet utgör en omfattande och ingående analys av oaktsamheten. Huvudvikten ligger på den objektiva sidan, på gärningsculpan men även den personliga sidan tas upp. Boken har recenserats på svenska av Dan Frände i JFT 1997 s. 212-222. Följande år (1997) kom Petri Jääskeläinens likaså omfattande avhandling om åklagaren som domare ("Syyttäjä tuomarina"). P.O. Träskman fungerade som fakultetsopponent och hans recension finns publicerad i JFT $1997 \mathrm{~s}$. 515-529. I sammanhanget bör även Heikki Pihlajamäkis rättshistoriska avhandling "Evidence, Crime, and the Legal Profession" från 1997 nämnas.

Den teoretiska straffrätten dominerar starkt i Kimmo Nuotios avhandling "Teko, vaara, seuraus. Rikosvastuun filosofisista, kriminaalipoliittisista ja lainopillisista perusteista" (Gärning, fara, följd. Om straffansvarets filosofiska, kriminalpolitiska och rättsdogmatiska grunder), som utkom 1998. Under 1999 utkom Matti Tupamäkis avhandling om utsträckningen av statens straffrättsliga behörighet i folkrätten ("Valtion rikosoikeudellisen toimivallan ulottuvuus kansainvälisessä oikeudessa"). Boken, som är skriven på finska, har folkrätten som utgångspunkt men handlar till stora delar om första kapitlet i SL. En recension av fakultetsopponent Jan Klabbers finns publicerad på engelska i Lakimies 4/2000 s. 641-647.

Matti Tolvanen disputerade 1999 på en avhandling om vägtrafikstraffrätt och kriminalpolitik ("Tieliikennerikokset ja kriminaalipolitiikka"). Boken har recenserats på svenska av Dan Frände i JFT 1-2/2000 s. 191-197. Periodens sista doktorsavhandling utkom hösten 2000 och har skrivits av Marianne Wagner-Prenner. Boken handlar om tillräknelighet och sinnestillstånd ("Syyntakeisuus ja mielentila").

Ytterligare bör två avhandlingar nämnas. Jukka Lindstedt disputerade 1999 på en rättshistorisk avhandling ("Kuolemaan tuomitut. Kuolemanrangaistukset Suomessa toisen maailmansodan aikana") om dem som dömdes till dödsstraff i Finland under andra världskriget. Ari Hirvonens avhandling "Oikeuden käynti. Antigonen laki ja oikea oikeus" (2000) hör till området för rättsfilosofin . Arbetet har också anknytning till straffrätten, eftersom Antigone begick ett brott varvid vi får anledning att fråga efter naturen hos det vi kallar brott.

b. Antalet monografier är rätt betydande, något som delvis förklaras av den moderna trycktekniken. De flesta har som grund ett licentiatarbete och de saknar genomgående sammanfattningar på något annat språk än finska.

I Jaakko Rautios bok "Rangaistusmääräysmenettelystä” från 1996 tas till grundlig behandling det i praktiken mycket viktiga strafforderförfarandet.

Matti Nissinen behandlar i sin bok "Rikosvastuun kohdentamisesta yhteisössä" (1997) utförligt frågor i anslutning till hur det straffrättsliga ansvaret skall fördelas i organisationer. "Vastuun kohdentaminen" är ett typiskt finskt begrepp och brukar översättas som "allokering av straffansvaret". Enligt Nissinen kommer man långt med de normala reglerna för oaktsamhet och underlåtenhet. Dock har lagstiftaren i SL 47:7 och 48:7 tagit explicit ställning till frågan om ansvarsfördelningen vid arbets- och miljöbrott, varför allokeringen av straffansvar har relevans som en dogmatisk begreppskonstruktion. Till samma problemkomplex hör även Vilja Hahtos undersökning av ansvaret för arbetsskyddet ("Kuka vastaa työturvallisuudesta", 1998).

Pasi Pölönens undersökning "Salaiset pakkokeinot" från 1997 har de 1995 tillkomna tekniska tvångsmedlen i TvångsmedelsL 5a kap. som objekt. Hit hör bl.a. hemlig avlyssning av telefoner och spårning. Samma ämne, dock begränsat till hemlig avlyssning av telefoner, behandlas av Essi Kinnunen i boken "Telekuuntelu" (1997). 
Päivi Hirveläs bok "Lapsi rikosprosessissa erityisesti insestin todistamisen ongelmat" (1997) handlar om barnets ställning i straffprocessen. Särskild uppmärksamhet ägnar hon bevisvärdet hos barnets berättelse, när det gäller att leda ett åtal om incest i bevis. Arbetet ger en mångsidig och väldokumenterad bild av de svårigheter som hör samman med bevisningen $\mathrm{i}$ incestmål.

Markku Salminen publicerade 1998 en omfattande undersökning av gäldenärsbrotten ("Velallisen rikos"). Hans idé är att ur ett förundersökningsperspektiv lyfta fram det intressanta i gäldenärsbrotten. Salminen lägger fram en rad påståenden om den moderna ekonomiska brottsligheten. Han utgår entydigt från att gäldenären i en krissituation oftast handlar rationellt och detta bör förundersökningsledaren ha som utgångspunkt för sina åtgärder. Salminen kritiserar även utformningen av gäldenärsbrotten och menar att SL 39 kap. inte är en välavvägd helhet. Inte heller domstolarna får högsta betyg, eftersom de ofta saknar nödvändig insikt i grunderna för ekonomisk redovisning. Som helhet är Salminens undersökning intressant och utmanande, om än något svåröverskådlig.

Heikki Jaatinens bok om juridiska personers straffansvar ("Oikeushenkilön rangaistusvastuu", 2000) ger en komprimerad bild av innehållet i SL 9 kap. Förutom de allmänna förutsättningarna för utdömande av samfundsbot går Jaatinen bl.a. igenom själva straffmätningen samt flera straffprocessuella frågeställningar. Boken utgör den första mera heltäckande behandlingen av det 1995 införda straffansvaret för juridiska personer.

Timo Loman behandlar i sin bok "Poliisin oikeudesta käyttää voimakeinoja" från 1997 rätten för polisen att använda maktmedel. I samband med reformen av polislagstiftningen 1995 flyttades reglerna till PolisL . Samtidigt fick de en något moderniserad utformning.

Essi Kinnunen tar upp ett aktuellt tema i verket "Rangaistava toisen vahingoittaminen urheilussa" (1999), dvs. situationer där idrottsmän i samband med idrottsutövning tillfogar varandra fysiska skador.

Joonia Streng analyserar i boken "Eläinsuojelu ja rikosoikeus" (1999) förhållandet mellan djurskydd och straffrätt. Fastän djurskyddets kopplingar till straffrättens allmänna läror blir rätt lösa, tar boken upp ett mycket aktuellt tema bl.a. till följd av de attacker som har gjorts mot pälsdjursnäringen i Finland under 1990-talet.

Tapio Lakanen tar i verket "Virkamiehen väkivaltainen vastustaminen" (1999) ställning till en rad tolkningsfrågar som hör samman med brottet våldsamt motstånd mot tjänsteman (SL 16:1). Temat är aktuellt eftersom lagstiftningen ändrades 1.1.1999.

Sanna Heikinheimo undersöker i boken "Rahanpesu erityisesti kriminalisoinnin ja konfiskaation näkökulmasta" (1999) penningtvätt ur flera synvinklar. Uppmärksamhet ägnas inte bara dogmatiska frågeställningar (straffbestämmelsen om penningtvätt SL 32:1 ingår i finsk rätt sedan 1994) utan även empiri och kriminalpolitik berörs.

Målsägandens ställning i straffprocessen behandlas av Mikko Vuorenpää i boken "Asianomistajan oikeudet rikosprosessilaissa" (1999). Författaren går igenom gällande regler om målsägandens rättigheter och skyldigheter. Temat är både utmanande och intressant, eftersom målsägandens ställning genomgick en betydande metamorfos i samband med straffprocessreformen 1.10.1997.

Laura Ervos bok "Esitutkinnan optimaalisuus oikeudellisessa viitekehyksessä” (2000) utgör ett försök att analysera förundersökningen ur ett diskursetiskt perspektiv. Härvid spelar värden som förtroende, rättsskydd och serviceinriktning en central roll.

Ytterligare bör nämnas det tvådelade verket "Kirjoituksia talousrikollisuudesta I-II" från 1998 och 1999. Här ingår en rad kortare uppsatser med anknytning till den ekonomiska brottsligheten.

c. Kommentarer och läroböcker. 1995 gav Nuutila ut sin lärobok om straffrättens allmänna läror. Två år senare utkom en starkt utvidgad och delvis omsystematiserad version med titeln "Rikoslain yleinen osa" (Strafflagens allmänna del).

År 1999 blev så till vida ett märkesår för finsk straffrätt att då utkom en länge efterlängtad storkommentar till den finska straffrätten. Titeln "Rikosoikeus" (Straffrätt) säger klart vad det handlar om. Här gås de allmänna lärorna, de enskilda brotten och straffpåföljderna igenom på över 1100 sidor. Författarna är Olavi Heinonen, Pekka Koskinen, Tapio Lappi-Seppälä, Martti Majanen, Kimmo Nuotio, Ari-Matti Nuutila och Ilkka Rautio. 
Den finska straffprocessen reformerades 1997 och de nya reglerna har i läroboksform kommenterats av Antti Jokela ("Uudistuva rikosprosessi", 3 upplagan, 2000), Jyrki Virolainen ("Rikosprosessioikeus I", 1998) och Dan Frände ("Finsk straffprocessrätt I", 1999).

Polisrätten genomgick en grundläggande normativ nydaning 1995. Klaus Helminen, Matti Kuusimäki och Markku Salminen har 1999 gett ut en kommentar på finska ("Poliisioikeus"). Verket har av Klaus Helminen getts ut på svenska under rubriken "Polisrätt" (2000).

Pekka Viljanen har kommenterat de ändringar i reglerna för gemensamt straff som genomfördes 1.10.1997 i verket "Yhtenäisrangaistusjärjestelmän muutokset" (1998). Antero Kaila har behandlat reglerna i SL 45 kap. om militära brott ("Sotilasrikokset", 1997), Matti Tolvanen det 1999 reformerade SL 23 kap. om trafikbrott ("Tieliikennerikokset", 1999) och Jussi Matikkala SL 21 kap. om brott mot liv och hälsa ("Henkeen ja terveyteen kohdistuvat rikokset", 2000).

Avslutningsvis kan nämnas att 1998 inleddes utgivningen av kommentarer till HD:s publicerade avgöranden. Serien har nu utkommit i 5 band och utgör ett mycket betydelsefullt tillskott i den rättsdogmatiska litteraturen i Finland. 